\title{
Theories of Property and Economic Development
}

\author{
Joshua Getzler
}

Journal of Interdisciplinary History, Vol. 26, No. 4. (Spring, 1996), pp. 639-669.

Stable URL:

http://links.jstor.org/sici?sici=0022-1953\%28199621\%2926\%3A4\%3C639\%3ATOPAED\%3E2.0.CO\%3B2-F

Journal of Interdisciplinary History is currently published by The MIT Press.

Your use of the JSTOR archive indicates your acceptance of JSTOR's Terms and Conditions of Use, available at

http://www.jstor.org/about/terms.html. JSTOR's Terms and Conditions of Use provides, in part, that unless you have obtained prior permission, you may not download an entire issue of a journal or multiple copies of articles, and you may use content in the JSTOR archive only for your personal, non-commercial use.

Please contact the publisher regarding any further use of this work. Publisher contact information may be obtained at http://www.jstor.org/journals/mitpress.html.

Each copy of any part of a JSTOR transmission must contain the same copyright notice that appears on the screen or printed page of such transmission.

The JSTOR Archive is a trusted digital repository providing for long-term preservation and access to leading academic journals and scholarly literature from around the world. The Archive is supported by libraries, scholarly societies, publishers, and foundations. It is an initiative of JSTOR, a not-for-profit organization with a mission to help the scholarly community take advantage of advances in technology. For more information regarding JSTOR, please contact support@ jstor.org. 
Journal of Interdisciplinary History, xxvI:4 (Spring, 1996), 639-669.

Joshua Getzler

\section{Theories of Property and Economic Development}

According to economic theory, the clear definition of property rights is essential for well-functioning markets. Comparatively little attention, however, is given to explaining the development of these rights. Economic reasoning suggests that markets themselves call property rights into existence: Persons contract to set up institutions enforcing stable, definite entitlements to scarce resources in order to facilitate investment, production, and exchange. Thus, contracts constituting property rights and institutions precede those contracts dealing with existing property rights; both can be conceived as market transactions made in pursuit of gains. As McCloskey observes, in order to understand the emergence and function of property rights, economics "enlists the theory of self-interest to define the very object of self-interested desire."

An historical approach to the development of property rights may suggest further explanation adding to the economist's parsimonious theory. Economic institutions and activities need not be subsumed within purely economistic interpretations; they are also susceptible to legal and historical analysis. Much can be learned from studying the ideas, institutions, and laws of property during England's pioneering industrialization in the eighteenth and nineteenth centuries - the period known as the Industrial Revolution. This essay in the history of ideas describes the origins of the modern economic theory of property. The theory traces back to nineteenth- and twentieth-century historical and social-scientific

Joshua Getzler is University Lecturer, Faculty of Law, and Fellow of St. Hughes College, University of Oxford. He is the author of "Unconscionable Conduct and Unjust Enrichment As Grounds for Judicial Intervention," Monash University Law Review, XVI (I990), 283-326.

(C) 1996 by the Massachusetts Institute of Technology and the editors of The Journal of Interdisciplinary History.

I Donald N. McCloskey, The Applied Theory of Price (New York, I982; Ist ed.), 359; Ronald H. Coase, "The Problem of Social Cost," Journal of Law and Economics, (1960), III, I-44, reprinted in idem, The Firm, The Market and the Law (Chicago, 1988), 95-106; Harold Demsetz, "Towards a Theory of Property Rights," American Economic Review, LVII (1967), 347-359; Gary Libecap, Contracting for Property Rights (Cambridge, I989), I-28; Yoram Barzel, Economic Analysis of Property Rights (Cambridge, I989); Thrainn Eggertsson, Economic Behaviour and Institutions (Cambridge, I990), 33-58. 
models of the Industrial Revolution. The sources of property theory in the world of the classical economists are now forgotten, and this lapse of memory has blunted the critical self-consciousness necessary for the theory to be effective and fruitful. The solution lies in a restoration of historical self-consciousness and an openness to alternative disciplinary approaches. ${ }^{2}$

Blanqui early suggested the concept of an "industrial revolution" commencing in mid- to late eighteenth century England and contrasting with the political revolution in France. Although some quantitative historians of the New Economic History school have rejected the notion of a sudden sequence of rapid economic change in this period, the consensus of modern scholarship still accepts that a radical and unprecedented growth and restructuring of the British economy can be identified around I800, making this period a watershed in human history. ${ }^{3}$

An older generation of institutionalist economic historians gave close attention to the impact of law and government on the course of the Industrial Revolution, examining Poor Laws, enclosure statutes, and labor and guild regulations; but these concerns were submerged with the rise of quantitative and neoclassical historical methodologies known as the New Economic History. Crafts, in a survey of new Industrial Revolution historiography, concluded that "relatively little has been done . . . in seeking to investigate the impact of changes in the law and other institutional arrangements on economic efficiency." This statement perhaps underestimates the state of the art, for much has been achieved in disciplines contiguous to quantitative economic history. In

2 Alexander Field, "Do Legal Systems Matter?" Explorations in Economic History, XXVIII (I99I), I-35, 2-7, 3 I-33; Armen A. Alchian and Demsetz, "The Property Rights Paradigm," Journal Of Economic History, XXXIII (1973), I6-27.

3 Jerome-Adolphe Blanqui, Histoire de l'Economie Politique (Paris, I837), 389. See also Anna Bezanson, "The Early Uses of the Term Industrial Revolution," Quarterly Journal of Economics, XXXVI (I92 I/2), 343-349; Paul Mantoux (trans. Marjorie Vernon), The Industrial Revolution in the Eighteenth Century (London, 1928); Roderick Floud and Donald N. McCloskey (eds.), The Economic History of Britain Since 1700, Vol. I 1700-1860 (Cambridge, 1981; 2d ed., 1994); Joel Mokyr (ed.), The Economics of the Industrial Revolution (London, I985); idem (ed.), The British Industrial Revolution: An Economic Perspective (Boulder, I993); David Cannadine, "The Present and the Past in the English Industrial Revolution 1880-1980," Past and Present, 103 (I984), I3I-I72; E. Anthony Wrigley, People, Cities and Wealth: The Transformation of Traditional Society (Oxford, I987); Julian Hoppit, "Counting the Industrial Revolution," Economic History Review, XLIII (I990), I73-I93; Maxine Berg and Pat Hudson, "Rehabilitating the Industrial Revolution," Economic History Review, XLV (I992), 24-50. 
particular, legal historians and legal economists have developed a variety of powerful interpretations explaining the role of property rights and legal institutions in fostering economic development; and this work is available to enrich and inform the history of industrialization, as well as economic theory. ${ }^{4}$

INSTRUMENTAL AND EXPRESSIVE THEORIES OF PROPERTY TheOries of property in the Western philosophical tradition divide roughly in two. There is a notion of property as presocial, a natural right expressing the rights of persons which are prior to the state and law, this being the view of Hugo Grotius, Samuel von Pufendorf, John Locke, Immanuel Kant, and Georg W. F. Hegel; and there is a notion of property as social, a positive right created instrumentally by community, state, or law to secure other goalsthe theory of Thomas Hobbes, David Hume, Adam Smith, Jeremy Bentham, Emile Durkheim, and Max Weber. The expository line between these theories blurs, and their analysis has yielded a large and intricate philosophical literature. The concerns of this essay lie elsewhere, with the practical operation of concepts of property in law and economy, especially in England from 1770 to $1870 .^{5}$

In the history of English political thought, it is the positive tradition of property theory that is most important in modern times, because it was integral to classical political economy and utilitarian philosophy. Yet, one of the few vigorous natural-right strands of the English political tradition, especially on the right of politics, has been the idea of the sanctity of private property rights - in particular, the immunity of individual property entitlements to the claims of public welfare. This idea is to be found in many distinct forms; one expression is the Lockean tradition, and another, the common-law tradition of Coke and Blackstone. The roots of English individualism and absolute respect for property have been traced back to England's distinct medieval system of

4 Peter McClelland, Causal Explanation and Model Building in History, Economics, and the New Economic History (Ithaca, I975); Mokyr (ed.), Economics of the Industrial Revolution; idem (ed.), British Industrial Revolution.

5 See Lawrence C. Becker, Property Rights: Philosophical Foundations (London, 1977); Alan Ryan, Property and Political Theory (Oxford, 1984); Jeremy Waldron, The Right to Private Property (Oxford, I988); Stephen Buckle, Natural Law and the Theory of Property (Oxford, I99I). For a critical review of the abstraction and ahistoricism of much recent philosophical analysis, see Becker, "Too Much Property," Philosophy and Public Affairs, XXI (I992), 196-206. 
landholding and property law; and a religious element may also be identified, for example in the seventeenth-century Puritans' insistence on the sanctity of property against monarchical authority. ${ }^{6}$

The naturalist ideology of the sanctity of property was especially appealing to the powerful class of landowners and to the legal functionaries that they supported. Other less powerful groups might stress different natural rights, such as customary communal rights or public rights to enjoyment of the land. The tension between contending property ideals held by different fractions of the propertied and unpropertied classes was evident throughout the span of industrialization, from the late eighteenth century onward, reaching a final climax in the Liberal assault on the landed interest during the late Victorian and Edwardian period. ${ }^{7}$

PROPERTY AS CERTAINTY OF EXPECTATIONS

The most powerful strain of property theory in economic thought has been instrumentalist rather than naturalist, as exemplified in Smith's Wealth of Nations, and later in the philosophy of Bentham-of all the Philosophical Radicals the most legalistic and attentive to the details of social institutions. Bentham advocated a property regime promoting security of individual title, possession, and control to maximize the individual "calculation of chance" essential to capitalist production and trade. Property, according to Bentham, was "nothing but a basis of expectation," and the institution of property failed if expectations of obligation and interest were not made clear. $^{8}$

6 Locke, Second Treatise of Government, ch. 9, ss. 123-127, in Peter Laslett (ed.), Two Treatises of Government (Cambridge, I963), 395-397; Edward Coke, The First Part of the Institutes of the Laws of England, or, A Commentary on Littleton (London, I628); William Blackstone, Commentaries on the Laws of England (Oxford, I765-I769), I, I23-I40; Alan Macfarlane, The Origins of English Individualism (London, I978); David Little, Religion, Order and Law (Oxford, I970); Crawford B. Macpherson, The Political Theory of Possessive Individualism: Hobbes to Locke (Oxford, I962).

7 Edward P. Thompson, "Custom, Law and Common Right," in idem, Customs in Common (London, I99I), 97-I84; Avner Offer, Property and Politics, 1870-1914 (Cambridge, I98I); Richard B. Schlatter, Private Property: The History of an Idea (London, I95I).

8 Adam Smith (ed. Edwin Cannan), An Inquiry into the Nature and Causes of the Wealth of Nations (London, I904), I, 267; II, 207; see also idem, Lectures on Jurisprudence (Oxford, I978), 459-472; Neil MacCormick, "Law and Economics: Adam Smith's Analysis," in idem, Legal Right and Social Democracy (Oxford, I982), I03-125; Jeremy Bentham (ed. Herbert L. A. Hart), Of Laws in General (London, I970), III-II2, and, generally, I09-I98); idem (ed. Richard Hildreth), The Theory of Legislation: Principles of the Civil Code (London, I891, 2d ed.); Hart, Essays on Bentham (Oxford, I982). 
The orthodox utilitarian claim that private property rights are desirable because they are conducive to certainty and efficiency was often challenged with another utilitarian argument that alternative forms of property can often do the job of resource allocation with more beneficial results than a regime of crystallized, sharply defined individual rights of appropriation-for example; such non-private property holdings as the public trust, common rights, and other legal forms of public and communal goods. The later utilitarians and classical economists questioned the desirability of allowing any landed private property. Ricardo held that, in a mature capitalist economy, private landownership was an unproductive monopoly extracting rents from commerce and industry. Malthus gave this idea an optimistic gloss, holding that the idle and luxurious consumption of land rents helped to sustain effective demand and so promoted full employment of the economy's resources. Marx added that this monopoly was tolerated within the capitalist system only because landownership was the archetype of all private property rights, the model of capitalist power to appropriate surplus value. But these classical arguments were concerned exclusively with the optimal arrangement of resources for maximized production and welfare, rather than with countervailing values such as social equity or civic virtue. A more radical tradition argued that the rise of the possessive and atomistic individualism entailed by pure forms of private property holding produced an unjust and unattractive civilization, whatever the aggregate utilities of production. ${ }^{9}$

UNCERTAINTY OF TITLE AND USER Historically the most infamous aspect of England's property-law regime, which attracted the attention of generations of distinguished radicals, from the seventeenth-century Independents to Bentham and Lord Henry Brougham and others to follow, was the obstruction to free transfer of property, due to uncertainty of titles and the clumsiness

9 Thomas Malthus, The Principles of Political Economy (London, 1936; facs. repr. of $2 \mathrm{~d}$ ed. [1836]); David Ricardo (ed. Piero Sraffa), On the Principles of Political Economy and Taxation (Cambridge, I95I), 67-84, I73-175, I8I-190; John Stuart Mill, Principles of Political Economy (London, I87I; 7th ed.), bk. II, ch. 2, s. I; bk. V, ch. 2, s. 7, in idem (ed. John Mercel Robson), Collected Works (Toronto, I965), II, I73-I85, I99-217; III, 819-824; Karl Marx, Capital (New York, I967), III, 821; David Harvey, The Limits to Capital (Oxford, I982), 330-372; Macpherson, Possessive Individualism; Christopher Hill, The World Turned Upside Down (Harmondsworth, I975); Thompson, The Making of the English Working Class (London, I968; 2d ed.; repr. I980); idem, Customs in Common. 
of the legal process of conveyance. The heavy transaction costs of land exchange and succession had many causes: archaic, irregular, and obscure legal rules of tenure, copyhold, and estates; monopolist charges extracted by the lawyers, who alone could define and convey those estates; the secrecy of titles desired by landholders who wished to protect their wealth from the threat of public taxation and private family claims; and overt legal barriers to transfer, which included family strict settlements and entails passing land exclusively to linear family descendants, and the residual precapitalist property forms of common rights. The Radicals of the nineteenth century believed that removal of these institutional frictions would bring in a host of benefits: a shift of resources by auction to the most efficient users, a breakup of the great estates (and power) of the landlords, a reduction of the professional rents extracted by lawyers, and a readier assessment and taxation of landed wealth. A parallel movement can be seen in Germany with the Pandectist movement-a group of liberal lawyers and historians who believed that changing the law of tenures and estates could effect a quiet but profound social and economic revolution. ${ }^{10}$

This essay emphasizes a different, less familiar story of conflict about the law of property, involving not the aspects of exchange and distribution but rather of production or user. Following Weber, we may ask, How did a country with such an irrational property system as England support the enclosure movement and industrialization? How could developers calculate the risks of investment when laboring under such uncertain entitlements? Neither the rights of title and transfer nor the rights of amenity permitting the exploitation of vested resources were sharply delineated. The anomaly of industrialization in an uncertain regime

Io Blair Worden, The Rump Parliament, 1648-53 (Cambridge, I974), I05-II 8, 265-298; Bernard Rudden, "A Code Too Soon, The I 826 Property Code of James Humphreys: English Rejection, American Acceptance, English Acceptance," in Peter Wallington and Robert Merkin (eds.), Essays in Memory of Professor F. H. Lawson (1986), IoI-II6. For a later phase see Offer, "The Origins of the Law of Property Acts I910-1925," Modern Law Review, XL (1977), 505-522; idem, Property and Politics; J. Stuart Anderson, "Land Law Texts and the Explanation of 1925," Current Legal Problems, XXXVII (1984), 63-83; idem, Lawyers and the Making of English Land Law 1832-1940 (Oxford, 1992); Getzler, Review Article, Law Quarterly Review, CIX (1993), 684-689; Offer, "Lawyers and Land Law Revisited," Oxford Journal of Legal Studies, XIV (1994), 269-278; James Q. Whitman, The Legacy of Roman Law in the German Romantic Era (Princeton, I990); idem, "Why Did the Revolutionary Lawyers Confuse Custom and Reason?" University of Chicago Law Review, LVIII (I99I), I32I-I368; Jerome Blum, The End of the Old Order in Rural Europe (Princeton, 1978). 
of property title and user constituted Weber's "England Problem," an exceptional case that seemed to contradict his general typology of legal and economic development in the West.

WEBER AND THE INSTITUTIONAL BIAS OF ENGLISH LAW To explain the anomaly of "backward" English law, Weber argued that during modernization the procedural and institutional structure of the common law was functionally more significant than the substantive or normative content of its rules. Weber found a deep historical divergence between the rationalized German civil law, based on Roman law, and the customary and precedent-based English common law-a distinction that "originates from the autonomous development of the two different structures of domination":

In England there was centralised administration of justice combined with domination by notables; in Germany there was no political centralisation but a high degree of bureaucratisation. Thus the first country in modern times to have a highly developed capitalist economy, England, retained a less rational and less bureaucratic system of justice. The main reason why capitalism in England was able to come to terms so well with this situation, however, was that in that country the manner in which the courts were organised and the trial procedure, right up until modern times, were in fact tantamount to a virtual denial of justice to the economically weak. This fact, together with the time consuming and costly procedure for conveyancing land, which is also the result of the economic interests of the lawyers, has in turn also deeply affected the agrarian system of England in the direction of the accumulation and immobilisation of land. ${ }^{11}$

Weber did not make clear how the agrarian and industrial revolutions of the eighteenth and nineteenth centuries were promoted or influenced by large estates "immobilizing" the land, or whether immobilization meant restraints on the transfer of land in an imperfect property market or else concentration of property into monopolist holdings. Moreover, Weber's leitmotiv of legal rationality as a general prerequisite of modernity and economic development is notoriously ambiguous. Weber often associated

I I Max Weber, “The Development of Bureaucracy and Its Relation to Law," from Wirtschaft und Gesellschaft [Economy and Society] (1922), reprinted in Walter Runciman (ed.), Max Weber: Selections in Translation (Cambridge, 1978), 352-354. 
rationality simply with governance by rules. Hence, a rational legal system was "a logically clear, internally consistent, and, at least in theory, gapless system of rules, under which, it is implied, all conceivable fact situations must be capable of being logically subsumed lest their order lack an effective guaranty." 12

The highest expression of this concept of rationality was held to be the developed Romanist law of the European countries, "the legal science of the Pandectists." However, legal rationality went beyond rule governance. Weber also stressed the role of law and lawyers in creating stability of property rights and predictability of contract enforcement through formal bureaucratic rule, whereby deliberately chosen norms were applied, rather than customary norms ("age-old rules and powers"), in order to resolve conflict and generate order.

In the exceptional case of England, Weber's main thesis seems to have been that the inequalities wrought by the adversarial and formalistic common-law system were a boon to the wealthy and energetic, who could carry out the transformation of the economy without challenge from the poor or the unproductive who could not afford to defend their rights. Weber also argued that the absence of formal legal rationality did not impede capitalist enterprise in England because the judges shared a developmental ideology with the entrepreneurial classes and were willing and able to mold the English system of precedent sufficiently to create legal conditions supporting certainty of business calculation. Weber characterized the English experience as a unique historical case, in which an irrational system of laws was controlled by procapitalist functionaries not generally present in other societies. ${ }^{13}$

I2 Weber's varied uses of the concept of formal legal rationality are examined in Anthony Giddens, Capitalism and Modem Social Theory (Cambridge, I97I), I78-184, 214-2I6; Robert Holton and Bryan Turner, Max Weber on Economy and Society (London, I984), I03-I30; Anthony Kronman, Max Weber (London, 1983), 37-95; Max Rheinstein, "Introduction," in idem (ed.) (trans. Edward Shils and Max Rheinstein), Max Weber On Law in Economy and Society (Cambridge, Mass., 1954); Wolfgang Schluchter, The Rise of Western Rationalism: Max Weber's Developmental History (Berkeley, I98I); Samuel J. Stoljar, "Weber's Sociology of Law," in Geoffrey Sawer (ed.), Studies in the Sociology of Law (Canberra, 196I), 3 I-56; David Trubeck, "Max Weber on Law and the Rise of Capitalism," Wisconsin Law Review (1972), 720-753. For a sensitive appraisal of theories of rationality and modernization, see E. Anthony Wrigley, "The Process of Modernization and the Industrial Revolution in England," Journal of Interdisciplinary History, III (1972), 225-259. Quotation from Rheinstein (ed.), Max Weber on Law in Economy and Society, 62.

I 3 See also Patrick Atiyah, The Rise and Fall of Freedom of Contract (Oxford, I979), I I2-I I 7; Morton Horwitz, The Transformation of American Law 1780-1860 (Cambridge, Mass., 1977), 
PRIVATE LAW AND PUBLIC LAW ADJUSTMENTS TO CAPITALISM

Four Criticisms of Weber In his attempt to align the legaleconomic facts with his theoretical models of legal rationality and the spirit of capitalism, Weber missed many of the influences that help to explain the adjustment of the English property system to the Industrial Revolution. First, and crucial, was the ready adaptation of existing ancient law to modern economic functionsnew private ordering using old legal forms. For example, trust law and the calculus of estates and perpetuities, designed for projecting family wealth across generations in a precapitalist society, provided the flexible instrument of equitable funds, allowing the accumulation and investment of circulating capital for business and municipal enterprise. Lease and mortgage law provided for the ready fragmentation of property interests that accompanied the capitalist division of economic functions. Legal tools for private planning of land use (easements and covenants) were extended, but, ultimately, there was little radical doctrinal innovation. Following Renner, private law can be seen here as an archaic form or institution that could sustain the new substance of capitalist property relations without requiring abrupt conceptual transformation. $^{14}$

The disaggregation or fragmentation of ownership made possible by the common law in England contrasts with the abstract property norms of the modern European civil law, as promulgated in the great codes of the nineteenth century. The modernizing

I-30; Christopher Brooks, "Interpersonal Conflict and Social Tension: Civil Litigation in England, I640-1830," in A. Lee Beier, David Cannadine, and James Rosenheim (eds.), The First Modern Society (Cambridge, 1989), 357-399. Alexis De Tocqueville maintained that in the case of France, in contrast to England, prerevolutionary elites were restrained by a heavily centralizing system of law, which the weak and poor could invoke to their advantage (The Old Regime and the French Revolution [1858; 4th ed.], 32-72, 289-300.

I 4 See William S. Holdsworth, A History of English Law (London, 1925), VII; F. H. Lawson and Bernard Rudden, The Law of Property (Oxford, I982; 2d ed.), 76-II 3, I25-I 58, I76-204; A. W. Brian Simpson, A History of the Land Law (Oxford, I986; 2d ed.), 208-29I; Rudden, The New River: A Legal History (Oxford, 1985), 208-248. For recent historical debates about the causal links between common law property forms and the modernizing economy, see William R. Cornish and Geoffrey de N. Clark, Law and Society in England 1750-1950 (London, 1989), I23-I36, I66-I72; Gerry Rubin and David Sugarman, "Towards a New History of Law and Material Society in England, I750-19r4," in idem (eds.), Law, Economy and Society in England, 1750-1914: Essays in the History of the English Law (Abingdon, 1984), I-I23; Karl Renner, The Institutions of Private Law and their Social Functions (London, 1949), 8I-250; Otto Kahn-Freund, "Introduction," ibid., I-43. Similar ideas may be found in classical common law theory, for example, Blackstone's metaphor for the law as an "old Gothic castle, erected 
drive, especially in Germany, toward "rational" forms of property, based on the Romanist concept of absolute ownership, owed more to the theorizing of idealist philosophers and the preoccupations of classicist jurists and historians than to the needs of capitalist manufacturing and commerce. The German lawmakers resorted to Roman and Civilian jurisprudence as they sought to frame the economic and social institutions of a new German nation-state; they believed that individual and absolute property was a universal progressive value that could overcome the subordination and backwardness of unfree tenurial societies. But absolute property often impeded the swift movement and deployment of resources and responsibilities necessary for development and modernization. Examples of areas of difficulty in the German code included the legal aggregation of shifting capital resources in which management of capital is divorced from ownership, as well as the legal mechanisms for the transfer of title in complex sale of goods transactions passing property rights through a long chain of production and trade. English common law may have owned no developed theory of property as ownership, but the model of the fee simple provided a practical approximation of ownership that did all the necessary work. A feudal and therefore relativist system of property such as England's, which readily allows splitting of proprietary interests between many persons, creates intense complexities of title, but an absolute property regime forced to disaggregate title by fictions faces still greater complexities. Therefore, Weber's legal "rationalism" was a conservative force, paradoxically bound more by time and place than was the pragmatic and evolutionary common law. ${ }^{15}$

Second, during the late eighteenth and early nineteenth centuries, the English common law was internally reforming and

in the days of chivalry, but fitted up for a modern inhabitant" (Blackstone, Commentaries, III, 268); Postema, Bentham, 3-38; Jeremy Waldron, "What is Private Property?" Oxford Journal of Legal Studies, V (1985), 3 1 3-349.

Is See Whitman, Legacy of Roman Law; Michael John, Politics and the Law in Late Nineteenth-Century Germany: The Origins of the Civil Code (Oxford, 1989); Herbert Jolowicz, "Political Implications of Roman Law," Tulane Law Review, XXII (I947), 62-8I; Peter Birks, "The Roman Law Concept of Dominium and the Idea of Absolute Ownership," Acta Juridica, (1985), I-37, I9-25; Barry Nicholas, An Introduction to Roman Law (Oxford, I962; $3 \mathrm{~d}$ ed.), I45-I 53; James Harris, "Ownership of Land in English Law," in Neil MacCormick and Birks (eds.), The Legal Mind: Essays for Tony Honoré (Oxford, I986), I43-I6I; Kronman, Weber, I $34-146$. 
shedding some of its most archaic features. Milsom describes the long evolution of English law as a process of dethronement of the jury by the judge; that is, the wide discretionary power of juries to determine fact and discover customary norms was replaced by judicial power to define the law and to restrict narrowly the issues of fact going to the jury. Moreover, the style of judicial reasoning shifted from the arcane craft of classifying disputes within the medieval forms of action to a process describing substantive principles by which to resolve present litigation and set precedents for the future. In other words, the English common law was developing into a "mandarin" system of professionalized, bureaucratic, predictable norms more akin to the European civilian systems. Weber recognized that rational legal procedures could count for more than rational legal rules and concepts, and acknowledged that "it was not, indeed, the greater appropriateness of the content of Roman law to the needs of emerging capitalism which was responsible for their victory on the Continent: all the specific legal institutions of modern capitalism are in fact alien to Roman Law and are of medieval origin." Roman law generally enjoyed the more rational procedures; but English law also moved slowly toward "rational procedures of evidence" in order to benefit the merchant class. ${ }^{16}$

The third argument acknowledges the evolutionary internal development of the common law, yet holds that the flexibility, predictability, and rationality of this legal order remained deeply flawed. The solution ultimately lay not in the courts, but in Parliament. When common-law adaptability and reform finally reached its limit, public and especially private and local legislation were readily made available to create the legal structures for development. Examples include eighteenth- and early nineteenthcentury parliamentary enclosure; incorporation of business enterprises and limitation of their liability for property damage as well as debt; compulsory acquisition and other statutory powers for transport and urban development; monopolist protections of

I6 See S. F. C. Milsom, Historical Foundations of the Common Law (London, I98 I; $2 \mathrm{~d}$ ed.), 33-50, 70-81, 243-246; idem, Studies in the History of the Common Law (London, 1985), I49-I89; John H. Baker, An Introduction to English Legal History (London, I990; 3d ed.), 63-II I. See also Frederick Pollock and Frederic William Maitland, The History of English Law Before the Time of Edward I (Cambridge, I898; 2d ed.; reissued I968), II, 598-674. Quotation from Weber, "The Development of Bureaucracy and Its Relation to Law," 353. 
vested property and its profits against the competitive market; and reform of entrenched common-law rules curbing powers of ownership, sale, and succession. ${ }^{17}$

Fourth, the unwieldy and uncertain features of English private law were further offset by another dimension of public law - the success of the post-I688 Constitution. The settlement of I688/9 was built around the regularity of rule-bound taxation by a Parliament dominated by a self-governing propertied class, making possible a system of stable public credit that protected the English state from financial crises, especially in wartime. This condition, in turn, protected property from arbitrary exactions by a centralizing state, and fostered a relative certainty of expectations vastly overshadowing the uncertainties of title and possession cultivated by the ramshackle common law. In other words, the costs of irrational private law were balanced by the benefits of a legitimate and effective system of public taxation. A stronger governmental participation in the definition and control of private property rights at the microeconomic level might have undermined the legitimacy and success of the larger fiscal system. North has argued that stable taxation and the resulting security of property rights was the key exogenous, or noneconomic, factor making Britain's pioneering industrialization possible. ${ }^{18}$

THE CASE OF WATER RESOURCES How do these large theories help to explain the practical links between property law and economic change? What was the effect of particular legal forms and institutions on the activities of entrepreneurs and capitalists who sought to innovate in early industrial societies? These questions are raised acutely by the law of property relating to a central resource of the English industrial revolution, used by millowners,

17 See Cornish and Clark, Law and Society in England, I-196; Albert Venn Dicey, Law and Public Opinion in England in the Nineteenth Century (London, 1914; 2d ed.); Simpson, "Legal Liability for Bursting Reservoirs: The Historical Context of Rylands v Fletcher," Journal of Legal Studies, XIII (1984), 209-264, 25I-254; idem, History of the Land Law, 270-29I.

I8 Peter Dickson, The Financial Revolution in England: A Study in the Development of Public Credit, 1688-1756 (London, I967; reissued 1992); Peter Mathias and Patrick O'Brien, "Taxation in Britain and France, 1715-1810: Comparison of the Social and Economic Incidence of Taxes Collected for the Central Government," Journal of European Economic History, V (1976), 60I-650; John Beckett, "Land Tax or Excise: The Levying of Taxation in Seventeenth- and Eighteenth-Century England," English Historical Review, C (1985), 285-308; John Brewer, The Sinews of Power: War, Money and the English State, 1688-1783 (London, 1989); Douglass C. North, Structure and Change in Economic History (New York, 1981), I47-170. 
miners, farmers, canal companies, and municipal utilities as an essential raw material, power source, and transport mediumflowing water. ${ }^{19}$

The regime of riparian water rights in England from I770 to I 870 presents a striking complexity and confusion of common-law entitlements accorded to property owners. Riparian doctrine was shaped by an inherent feature of its subject matter, namely, that flowing water is in a constant state of change and may be diverted, abstracted, or polluted by competing users, and hence destroyed. So a running stream cannot be appropriated or possessed in the way that land as a stable, immutable object of property can. ${ }^{20}$

This situation creates difficulties of legal characterization, for underlying the law's intricate structure of property rights corporeal and incorporeal, of tenures, estates, and trusts, lay an abiding principle of physical possession (or rights to the fruits of possession) as the foundation of right. No such firm anchor was available to describe riparian ownership, for the riparian proprietor does not "possess" water flow, in the sense of appropriating or controlling or occupying a stream to the exclusion of others. Other noncorporeal appurtenant property rights, such as covenants touching and running with land, and rights of air, light, support, and way, can be conceived broadly as servitudes over land-modes of enjoying one's own land through nonpossessory control of neighboring land (iura in re aliena, or "rights in a stranger's property," in the terminology of Roman or Civilian law). By contrast, the use of water privileges need not be entwined with the enjoyment of adjoining land, but might be claimed as an incident of value

I9 David Landes, The Unbound Prometheus: Technological Change and Industrial Development in Western Europe from 1750 to the Present (Cambridge, I969), 65-66, 95-99, I04; G. Nicholas von Tunzelmann, Steam Power and British Industrialization to 1860 (Oxford, I978); Dolores Greenberg, "Reassessing the Power Patterns of the Industrial Revolution: An Anglo-American Comparison," American Historical Review, LXXXVII (1982), I237-I26I; Robert Gordon, "Cost and Use of Water Power during Industrialization in New England and Great Britain: A Geological Interpretation," Economic History Review, XXXVI (1983), 240-259; Terry Reynolds, Stronger Than One Hundred Men: A History of the Vertical Water Wheel (Baltimore, I983); Gerard Turnbull, "Canals, Coal and Regional Growth during the Industrial Revolution," Economic History Review, XL (1987), 537-560.

20 See The Reading of Robert Callis upon the Statute of Sewers, 23 Hen. VIII c. 5 (I622), 78-79; (London, I824, 4th ed.), 97. See also Challoner v. Thomas (I608) I23 English Reports 718 (King's Bench); Brown v. Best (I747) 95 English Reports 557, 559 (King's Bench) per Dennison J.; Magistrates of Llinlithgow v. Elphinstone (I768) 3 Kames' Decisions (Scottish Court of Sessions) 33 I; Thomas E. Lauer, "The Common Law Background of the Riparian Doctrine," Missouri Law Review, XXVIII (1963), 60-107, 81-107. 
in itself, for example, as the common property of a number of individuals or of a collectivity, or as a res communes, a public good available for the enjoyment of all. ${ }^{21}$

Nineteenth-century courts commonly described water rights as naturally connected to land, in the sense that ownership or occupation of abutting land was necessary for appropriation of the benefit of a running stream. However, with the diversification of industrial and urban water uses in the later nineteenth century, enjoyment of water could be divorced from association with neighboring land and thus shown to be distinct from incidents of landownership such as light and air. The multiplication of legitimate users inevitably led to heightened conflict about appropriation of finite available water. The courts finally adhered to a natural incident theory of riparian rights, based on a discretionary standard of reasonable usage of natural flow that limited the class of legitimate users to riverbank owners and balanced the requirements of competing users. A large number of theories were considered, adopted and rejected, however, before the modern principles were settled c. I $860 .^{22}$

Many factors internal to the legal system made for the long instability of riparian doctrine: the complexities of the forms of tort action for the protection of possessory and nonpossessory interests in property; contending doctrine and policy regarding the principles of prescription and adverse possession; the slow and confused development of the law of easements and natural property rights and of modern doctrines of private nuisance law during the nineteenth century; the complexities of Roman law principles

2 I Oliver W. Holmes, The Common Law (Boston, I88I; repr. 1963), I92-I94; William S. Holdsworth, An Historical Introduction to the Land Law, (Oxford, I927), I2I-I3I, I76-I88; Lawson and Rudden, Law of Property, 40-64, 76-IO4, II4-I I 7; Paul Krieger (ed.) (trans. Peter Birks and Grant McLeod), Justinian's Institutes (London, 1987), 2.I.I.-5, 2.2.3.; Francis de Zulueta (ed. and trans.), The Institutes of Gaius (Oxford, 1946), 2.I4., 2.I4a., 2.29.; Theodor Mommsen and Paul Krueger (eds.) (trans. ed. Alan Watson), Digest of Justinian (Philadelphia, I985), 4V., I.8.2.pr. (Marcianus); I.8.4, 5. (Gaius); 8.I.8.pr. (Paul); 8.I.I 5.pr. (Pomponius); 8.I.19. (Labeo); 8.2.30. (Paul), 8.2.32. (Julian); 8.3.5.I. (Ulpain); 43.8.3.pr.-I.4. (Celsus); 43.I2.I.3. (Ulpian); William W. Buckland, "The Conception of Servitudes in Roman Law," Law Quarterly Review, XLIV (1928), 426-435; idem, A Textbook of Roman Law from Augustus to Justinian (Cambridge, 1963; 3d ed.; repr. 1975), 180-189, 24I-252, 259-268; Herbert Jolowicz and Barry Nicholas, Historical Introduction to the Study of Roman Law (Cambridge, I972; 3d ed.), I56-I 58; 268-270.

22 Lord Blackburn noted in Orr Ewing v. Colqhoun (I 877) 2 Appeal Cases 839 (House of Lords, Scotland) that the natural right doctrine "can hardly be considered as settled law in England before the case of Mason v. Hill (I Io English Reports 692 [King's Bench]) in I 833." 
which were invoked as a model or starting point for the evolution of many of the modern English land-use rules; the uneasy relationship between common-law rights and equitable rights and remedies (especially the role of mandatory injunction in shaping property entitlements); and the judicial and statutory reforms simplifying procedure and concentrating discretionary power in the hands of the judges at the expense of juries.

Ultimately, the common law's capacity to govern water entitlements proved inadequate, and an ad hoc regime of private (and later public) statute was invoked to perform the task. But the common law served as the background or baseline for the statutory reordering of rights. Private bill proceedings in Parliament invoked common-law principle; and the Courts looked through common-law spectacles as they strove to interpret and apply the many hundreds of private and public acts issuing from Parliament. ${ }^{23}$

That resource developers dependent on water supply labored under legal uncertainty is abundantly suggested by their incessant quarrels, litigations, and Parliamentary contests concerning water rights. At least 200 water cases are reported between 1770 and I 870; many hundreds more may have eluded the central recordsfor example, at the preliminary circuit trials and in actions before local courts. Conflicts about flowing water could be fought by industrialists and landowners outside the courts, but very much in the shadow of the law. Moreover, there were numerous contested proceedings for the passing of private legislative bills in the committees of the Lords and Commons that closely resembled courtroom litigation. One such instance involved the proceedings on the Cromford Canal Acts, in which a canal company, seeking to appropriate land and water in order to provide cheap navigation for coal and heavy goods to Derbyshire, used a parliamentary bill to overcome fierce opposition from local millowners and landowners fearing loss of resources and damaging competition. The same style of conflict may be observed concerning common-law

23 See, for example, Rex v. Directors of the Bristol Dock Company (18 10) 104 English Reports 167 (King's Bench), in which Lord Ellenborough declined to allow compensation under a statutory stipulation that would have permitted no private common-law right of damages in the absence of such a public stipulation. 
and statutory rights to agricultural and industrial land during enclosure. $^{24}$

LEGAL UNCERTAINTY AND ANALYSIS OF THE INSTITUTION OF PROPERTY IN CAPITALISM The highly unstable regime of water and land-use titles provided by common law and statute requires more discriminating explanation of the relationship between property, law, and economic development at the level of entrepreneurial decision making. Guidance is available in the ideas of the institutional economists and the legal realists of early twentieth-century America-economists and lawyers such as Commons, Hale, Hohfeld, and Cohen. These writers, like those of the German historical school, theorized about the origins of property rights as part of their criticism of analytical economics. ${ }^{25}$

Property as a Bundle of Nested Rights According to the early institutionalists, property is more than merely a right of exclusive possession against all the world. It is a bundle of nested rights, that is, rights building upon each other, which include (I) possession of the physical thing owned, exclusive occupation; (2) rights to exploit, change, reorder, and manage; (3) rights to the flow of income from rights I and 2; (4) rights to transfer, exchange, and destroy rights I, 2, and 3; and (5) rights to transfer right 4 .

Modern legal and economic uses of the concept of property tend to emphasize the abstract rights 3,4 , and 5 , shifting from the

24 See, for example, Richard Arkwright, Correspondence with Sir Christopher and Sir M. M. Sykes re water rights, etc., at West Beck and Wansford Mills, Hull University Library, Personal Papers (1789-1822), 345-346; idem, Deeds and papers related to mill at Bakewell, East Sussex Record Office, Cavendish private records, Arkwright, I-97; Arkwright v. Gell (I839) I5I English Reports 87 (Exchequer); House of Lords Journals, XXXVII-XXXIX (1789-90); House of Lords Petitions (1789); House of Lords Committee Book. XXXIII (I789). For the conflict concerning agricultural and industrial rights, see text accompanying notes $46-48$.

25 McCloskey, Applied Theory of Price, Ist ed., 358; 2d ed., 339; John R. Commons, Institutional Economics (New York, 1934); idem, Legal Foundations of Capitalism (New York, 1924); Robert Hale, "Coercion and Distribution in a Supposedly Non-Coercive State," Political Science Quarterly, XXXVIII (1923), 470-494; idem, Freedom Through Law: Public Control of Private Governing Power (New York, 1952); Wesley Hohfeld, Fundamental Legal Conceptions as Applied in Judicial Reasoning (New Haven, 1919); Morris Cohen, "Property and Sovereignty," Cornell Law Quarterly, XIII (1927), 8-30; idem, "The Basis of Contract," Harvard Law Review, XLVI (1933), 553-592. For modern surveys see Morton Horwitz, The Transformation of American Law: The Crisis of Legal Orthodoxy, 1870-1960 (New York, 1992), 145-246; Neil Duxbury, "Robert Hale and the Economy of Legal Force," Modern Law Review, LIII (1990), 42 I-444; Warren J. Samuels (ed.), Institutional Economics (Aldershot, 1988); idem, The Economy as a System of Power (New Brunswick, 1979), I, 334-393. 
"physicalist" notion of property represented by rights I and 2 . The right to flow of income and the right to transfer (and thus capitalize) this right become a paramount means of evaluating, dealing, and allocating resources; the value of an asset is determined by the present net value of income flow and the transferability of that flow. The company share or investment equity and the bond investment exemplify this transformation of property to a dephysicalized expectation of income divorced from association with the res, or real object. A telling example is the longstanding English practice of referring to land values in terms of yearly rent, and of real capital values as so many year's purchase. ${ }^{26}$

Property as a Coercive Monopoly Subject to Competitive Injury In the institutional perspective, property rights, whether held to be natural or social in their philosophical foundation, are in their actual operation coercive rights over the actions of others. Property generally is a form of control of necessary resources vested in certain groups or individuals, their rights being established by public power of law; private property, in practice, functions as a delegation of public power to a monopoly right holder. ${ }^{27}$

This coercive monopolist right is not absolute but can take the form, in Hohfeld's analytical language, of a right proper, a privilege, an immunity, or a power. Thus, a property right need not impose correlative duties of noninterference upon all third parties, but can legitimately be subjected to redistribution or destruction by the operation of other common-law rights, by markets, or by regulatory legislation. ${ }^{28}$

26 Cf. Lawson and Rudden, Law of Property, I-39; Tony Honoré, "Ownership," in idem, Making Law Bind: Essays Legal and Philosophical (Oxford, 1987), I61-192; John Finnis, Natural Law and Natural Rights (Oxford, 1980), I69-173; Offer, "Farm Tenures and Land Values in England, c.1750-1950," Economic History Review, XLIV (1991), I-20; Dickson, Financial Revolution; John G. A. Pocock, Virtue, Commerce and History (Cambridge, 1985), 51-71, 103-123; Kenneth J. Vandevelde, "The New Property of the Nineteenth Century: The Development of the Modern Concept of Property," Buffalo Law Review, XXIX (1980), $325-367$.

27 Hale, "Coercion and Distribution"; Cohen, "Property and Sovereignty"; Duxbury, "Robert Hale"; Horwitz, Crisis of Legal Orthodoxy, r6o-167. Locke's concept of property as a natural right made effective by social contract is compatible with this analysis (Second Treatise of Government, ch. ix, ss. I23-127, 395-397).

28 Hohfeld, Fundamental Legal Conceptions. For some of the juristic and economic implications of Hohfeld's analytical scheme, see Finnis, Natural Law and Natural Rights, 198-230; Duncan Kennedy and Frank Michelman, "Are Property and Contract Efficient?" Hofstra Law 
The monopolist right of property is diminished primarily by the prospect of competitive injury to physical control and income flow caused by the actions of rival property holders in exploiting their holdings, in the absence of any contractual relations between the rivals specifying the allocation of risks, externalities, and other costs. It can be difficult for the law to discriminate between legitimate price competition and coercive interference with assets, and even more difficult to balance competing physical calls on resources; there is a complex "relationship between the 'right' to private property and the legitimacy of injurious competition." In the words of Holmes, "[t]he absolute protection of property, however natural to a primitive community more occupied in production than in exchange, is hardly consistent with the requirements of modern business." The economy translates the conflicts and uncertainties of the market into a spectrum of risks that entrepreneurs assume according to their preferences. Moreover, the uncertainty of title and user rights gives rise to competition for the physical control and integrity of resources. ${ }^{29}$

Property Takings and Delictual Compensation Policies The traditional utilitarian insistence on the certainty of individual vested rights neglects the contending needs for the continuous reformation and destruction of entitlements as an aspect of asymmetric information and risk under capitalism. One task of an effective legal system is to resolve this tension between certainty and contingency in order to prevent property hardening into a rent-extracting monopoly. The preeminent solution of the law is to allow the more efficient actor or user to capture, expropriate, or diminish another's right to a resource, on condition of consensual purchase or the payment of delictual or tortious compensation (outside legitimate price competition in which no compensation is required). But compensated takings or interferences can still

\footnotetext{
Review, VIII (1980), 7I I-770; Joseph Singer, "The Legal Rights Debate in Analytical Jurisprudence from Bentham to Hohfeld," Wisconsin Law Review (1982), 975-1059; Horwitz, Crisis of Legal Orthodoxy, I5I-156.

29 The early modern common law could regard the income generated by a fixed capital investment as protected from interference no less than the physical asset itself. Cf. Sury $v$. Pigot (1625) 79 English Reports 1263; 8I English Reports 280 (King's Bench). For analysis of common-law attitudes to price competition, see Charles River Bridge v. Warren Bridge (I 829) 7 Pick. 344, 352 (Mass.); Horwitz, Transformation of American Law, 1780-1860, I30-139; idem, Crisis of Legal Orthodoxy, I54; Holmes, The Common Law, 80; idem, "Privilege, Malice, and Intent," Harvard Law Review, VIII (I894), I-I4.
} 
present a major threat to the stability of entitlements. Compensation is not always forthcoming, nor need it preserve the status of the dispossessed owner. The law can simply refuse to recognize a person's property right as attracting remedial protection, as in the case of the extinguishment of "uncertain" and "unreasonable" common rights during enclosure. Alternatively, the invasion of a recognized legal right can be held to be reasonable and hence without negative legal sanction-damnum sine injuria, in legal phrase, or damage without right infringement or breach of duty. Another solution is to do away with rigid individual entitlements altogether and create new forms of communal or public goods governed by flexible, discretionary standards of "reasonable usage" that are simpler and cheaper to police than sharply defined standards of private ownership. ${ }^{30}$

The early institutionalists tended to assert blandly that compensation policy and the choice of property forms were questions involving pragmatic shaping of entitlements in the communal interest by the state. More recently, however, economists and legal theorists with less faith in the expertise and neutrality of state regulation have sharpened the characterization of such policies, suggesting that the legal system often embodies political choices made in an arena of conflict. They have cultivated a number of theories explaining the evolution of property rights in the period of modernization in Britain and America. ${ }^{31}$

\section{FIVE THEORIES OF THE DEVELOPMENT OF PROPERTY RIGHTS}

The Subsidy Theory-Unequal Burdens of Development

The subsidy theory suggests that property rights function as a means

30 Coase, "The Problem of Social Cost"; Guido Calabresi and A. Douglas Melamed, "Property Rules, Liability Rules and Inalienability: One View of the Cathedral," Harvard Law Review, LXXXV (1972), ro89-1128; Ashby v. White (The Aylesbury voters case) (1703) 92 English Reports 126, I37; 90 English Reports I188, I189 (King's Bench) per Holt C. J. Examples of communal goods can be found in natural-resource law from the midnineteenth century in England and America. See Carol Rose, "The Comedy of the Commons: Custom, Commerce and Inherently Private Property," University of Chicago Law Review, LIII (I986), 7I I-781; idem, "Crystals and Mud in Property Law," Stanford Law Review, XL (1988), 577-610; idem, "Energy and Efficiency in the Realignment of Common-Law Water Rights," Journal of Legal Studies, XIX (1990), 26I-296; Thomas W. Merrill, "Trespass, Nuisance, and the Costs of Determining Property Rights," Journal of Legal Studies, XIV (1985), I3-48.

3I All contemporary "law and economics" scholarship, whether written from a neoclassical or radical viewpoint, has been strongly influenced by public-choice theory. See, for example, Richard A. Posner, Economic Analysis of Law (Boston, 1992; 4th ed.), 519-537; Mark Kelman, $A$ Guide to Critical Legal Studies (Cambridge, Mass., 1987), I14-185. 
for dividing the burdens and benefits of development. The argument is that developers of land are given legal incentives for entrepreneurial activity by grant of protected monopolies safeguarding initial investment and sunk costs, and, further, that the law allows developers to impose external costs on neighboring landowners, labor, and other sectors in the course of the developers' land use, so that returns on capital are augmented and the profit drive of enterprise is not impeded. Only Kaldor-Hicks efficient results are required, that is, an increase in the global social product (or the appearance of one to lawmakers or adjudicators), even if that increase is detrimental to other parties. There is no policy of Paretian compensation to those whose position is worsened, even though such a model promotes stability of wealth and allows efficiency gains without necessitating inconvenient comparisons of varying interpersonal utilities due to changes in distribution.

Horwitz's influential The Transformation of American Law, $1780-1860$ is the leading work propounding this type of interpretation. Horwitz applies Marxist and Weberian approaches to the role of law in economy and society in order to structure a sweeping empirical study of the private law of New England and the eastern states during early American industrialization. The subsidy theory of Horwitz and others does not, however, explain how a pro-business, development-minded judiciary chooses between competing entrepreneurial activities involving conflicting land uses. The subsidy theory appears to assert that the legal system encouraged the entrepreneur imposing high external costs, as a presumptive maximizer of communal wealth. But it also suggests that because the protections, subsidies, and inequalities engineered by the legal system may have been inefficient or suboptimal in promoting sustained aggregate demand and production, as well as inequitable in failing to compensate, it may have distributed the losses and gains of innovation badly. ${ }^{32}$

The Transaction Cost Theory-Efficient Rules Addressing Market Failure The transaction cost theory characterizes property as an institution for the evolution of efficient rules addressing market

32 Lawrence Friedman, A History of American Law (New York, 1985; 2 d ed.); William Nelson, Americanization of the Common Law: The Impact of Legal Change on Massachusetts Society, 1760-1830 (Cambridge, Mass., 1975); James W. Hurst, Law and Economic Growth (Cambridge, Mass., I964); Harry N. Scheiber, "Law and the Imperatives of Progress: Private Rights and 
failure. This is the dominant theory, or set of theories, within the neoclassical and neoinstitutional traditions of economics, deriving from Coase's theorem. The central arguments are twofold. First, in the absence of transaction costs impeding perfect bargaining, exclusive, clearly defined private property, absolutely protected from injury (that is, through stringent compensation requirements), is the most efficient system of property law. The reason is that owners are ensured the full flow of income from their property and thus stimulated to develop their resources, and because they are able to calculate the returns on resources, trade them on the margin of profitable employment to more efficient users, and negotiate by contract the efficient assignment of costs. Under these conditions, legal assignment of property entitlements is of no significance to efficiency or the ultimate use of resources; goods move to the most able users through the mechanism of self-interested market transactions. Coase was concerned with efficiency results only; original assignment of property rights determine the range of efficient outcomes and the distributive results of the postulated free trade in rights. The first limb of the theory is essentially a reworking of the Paretian welfare assumption that free trade always promotes optimizing partial equilibria. ${ }^{33}$

The second part of Coase's theory states that, in the real world where transaction costs have a great significance, perhaps of a similar order of magnitude to production costs, the law often acts to assign property rights directly to the most efficient users, or those whose dealings are least impeded by transaction costs, so

Public Values in American Legal History," in J. Roland Pennock and John W. Chapman (eds.), Ethics, Economics, and the Law (New York, 1982), 303-320; Field, "Do Legal Systems Matter?," 26-29; Herbert Hovenkamp, "The Economics of Legal History," Minnesota Law Review, LXVII (1983), 645-697; Posner, Economic Analysis of Law, 256-26r; Gary T. Schwartz, "Tort Law and the Economy in Nineteenth-Century America: A Reinterpretation," Yale Law Journal, XC (198I), 1717-1775; idem, "The Character of Early American Tort Law," University of California Los Angeles Law Review, XXXVI (I989), 64I-7I 8; Simpson, "The Horwitz Thesis and the History of Contracts," University of Chicago Law Review, XLVI (1979), 533-60I; idem, Legal Theory and Legal History: Essays on the Common Law (London, 1987), 203-272.

33 Coase, "The Problem of Social Cost"; idem, "The Federal Communications Commission," Journal of Law and Economics, II, (I959), I-40, 23-27; George J. Stigler, The Theory of Price (New York, 1966; 3d ed.), I13; Demsetz, "Towards a Theory of Property Rights"; Posner, Economic Analysis of Law, 3-87. On the distributive implications of property right allocation, see Edward J. Mishan, "Pareto Optimality and the Law," Oxford Economic Papers, XIX (1967), 255-28I; Stigler, "Two Notes on the Coase Theorem," Yale Law Journal, XCIX (1989), 63 I-633; Field, "Do Legal Systems Matter?," Io. 
that the market will eventually establish the most efficient user. Likewise, compensation rules for property injury are explained in terms of minimizing transaction costs: Property entitlements are sometimes protected not by absolute property rules enjoining nonconsensual invasion, but by liability rules whereby the use and income flow of a resource can be injured by a competing actor who pays legally fixed compensation, akin to a forced sale, when consensual negotiation is impracticable. However, property injury may be permitted without compensation (a taking) when it is too expensive to identify and pay out injured owners, but gains in wealth from the invasion of rights exceed the cost of injury. ${ }^{34}$

The pressure of transaction costs could also lead to an order of common property instead of private property: for example, when governmental, communal, or customary control of resources can be provided cheaply to avoid resource mismanagement, when insurance costs for individual resource ownership are so high that communal property acts in substitution as an insurance pool, or when costs of policing and administering a strict private property system are prohibitive, that is, when evidence of invasion is expensive to collect. Hence, transaction-cost and property-right approaches to analysis of development do not always stress the efficacy of free markets, but sometimes the opposite, as in North's investigation of the role of property in economic history, which shows "that well specified property rights are not the same as

34 The extent of transaction costs in modern industrial organization is emphasized (perhaps exaggerated) by Coase, "The Institutional Structure of Production," American Economic Review, LXXXII (1992), 7 I 3-7I 9; cf. Oliver Williamson, The Economic Institutions of Capitalism, Firms, Markets, Relational Contracting (New York, 1985); North, "Economic Performance Through Time," American Economic Review, LXXXIV (I994), 359-368. Much depends on how transaction costs are defined. For an attack on the reductionist assumptions of transaction-cost analysis and the New Institutionalist Economics, see Robert D. Cooter, "The Cost of Coase," Journal of Legal Studies, XI (I982), I-33; James M. Buchanan, "Rights, Efficiency, and Exchange: The Irrelevance of Transaction Costs," in idem, Liberty, Market and State: Political Economy in the 1980s (Brighton, Sussex, I986), 92-I07; Posner, "Ronald Coase and Methodology," Journal of Economic Perspectives, VII (1993), I95-210.

For pollution problems and tortious injuries to land, see Calabresi and Melamed, "Property Rules, Liability Rules and Inalienability"; William M. Landes and Posner, The Economic Structure of Tort Law (Cambridge, Mass., 1987) I-53; Posner, Economic Analysis of Law, 3I-87. Beyond tort, there is little behavior touched by public or private law that has not been explained in terms of the simulation of a perfect market in property rights, though Coase wished to confine transaction-cost analysis to explicit market behavior. See Posner, ibid.; and idem, "Ronald Coase and Methodology." 
laissez-faire. The former were by far more important because they reduced transaction costs and thereby allowed more integrated markets, higher levels of specialization, and the realization of economics of scale." 35

Many fertile avenues of inquiry and explanation open up with transaction-cost analysis. To return to our case study, Rose has explained the evolution of eighteenth- and nineteenth-century water law during industrialization as a set of responses to transaction costs impeding optimal trading of entitlements between right holders. However, the basic assumption of the Coasean schoolthat common-law adjudication and judicial control of property, contract, and compensation rules, are inherently associated with efficiency and welfare goals-is not obvious. It is supported by controversial claims that judges consciously, or at least instinctively, understood efficiency considerations, or that an invisible hand of economic necessity or evolutionary social selection of norms propelled legal decision making. ${ }^{36}$

An extreme theory of an invisible judicial hand of efficiency is propounded by Posner. Public-choice theorists of the Chicago and Virginia schools have gone still further and suggest that judicial decision making is uniquely "neutral" and legitimate, compared to all other governing agencies. ${ }^{37}$

35 Elinor Ostrom, Governing the Commons: The Evolution of Institutions for Collective Action (Cambridge, I990); Rose, "The Comedy of the Commons"; cf. Garrett Hardin, "The Tragedy of the Commons," Science, CLXII (I968), I243-I248; McCloskey, "English Open Fields as Behaviour Towards Risk," in Paul Uselding (ed.), Research in Economic History, (1976) I, I24-I70; Carl Dahlman, The Open Field System and Beyond: A Property Rights Analysis of an Economic Institution (Cambridge, I980); Eggertson, Economic Behaviour and Institutions, 21 3-23 I; North, Structure and Change in Economic History, I 58-170.

36 Alchian, "Property Rights," in John Eatwell, Murray Milgate, and Peter Newman (eds.), The New Palgrave: A Dictionary of Economics (London, I987), III, I03 I-I034; Barzel, Economic Analysis of Property Rights; Cooter and Thomas Ulen, Law and Economics (New York, I988); Eggertsson, Economic Behaviour and Institutions; David Friedman, "Law and Economics," in The New Palgrave, III, I44-I 48; Erik Furobotn and Svetozar Pejovich, "Property Rights and Economic Theory: A Survey of Recent Literature," Journal of Economic Literature, X (1972), I I 37-I I62; Henry G. Manne (ed.), The Economics of Legal Relationships: Readings in the Theory of Property Rights (St. Paul, 1975); North, Institutions, Institutional Change and Economic Performance (Cambridge, 1990); Posner, Economic Analysis of Law, 3-87; Rose, "Energy and Efficiency"; cf. Robert G. Bone, "Normative Theory and Legal Doctrine in American Nuisance Law: I850 to I920." Southern California Law Review, LIX (I986), IIOI-I226, I $200-\mathrm{I} 226$.

37 Posner, Economic Analysis of Law, 25 I-268, 519-537; Kim Scheppele, Legal Secrets: Equality and Efficiency in the Common Law (Chicago, I988), 323. 
Modern studies have undermined the empirical veracity of such neutrality and efficiency claims. Alternative theories of the economics of adjudication may seem more persuasive: The classical model of Blackstone appreciated the risk of corruption through the self-interest of judges, but believed that common-law neutrality was protected by assigning the sensitive task of discretionary fact-decision to the jury, leaving judges to state the general principles of law only. But Blackstone also acknowledged that the ensuing system of formal rules and actions could be unwieldy and irrational. Modern theories suggest that stability and predictability, rather than efficiency or profit maximization, are often likely to be the thrust of private economic decision, even more so in the case of legal decision making. ${ }^{38}$

The simple neoclassical models of bargain-driven welfare assumed by Coasean theory are subject to challenge on a number of other counts. First, because the Coasean approach is embedded in the tradition of positive economics, it demonstrates a robust lack of interest in the fairness of initial distributions and economic power. Its sole concern is with instrumental market efficiency, not social efficiency. Second, Coasean analysis ignores endowment effects based on the psychological asymmetry of losses and gains, indicating a general preference for owners to maintain settled distributions and resist the efficient trade of rights even when such trade is possible. Third, Coase assumed too readily that optimizing bargains will always be struck in the absence of transaction costs; he eschewed engagement with strategic bargaining and game theories that demonstrate how fragile and contingent successful economic interactions can be. ${ }^{39}$

38 For modern criticisms of the efficiency theory of common law, see Schwartz, "Tort Law and the Economy"; David Kretzmer, "Transformation of Tort Liability in the Nineteenth Century: The Visible Hand," Oxford Journal of Legal Studies, IV (I984), 46-87; Robert S. Summers and Leigh B. Kelley, “Economists' Reasons for Common Law Decisions-A Preliminary Inquiry," Oxford Journal of Legal Studies, I (I98I), 213-255; Hovenkamp, "The Economics of Legal History"; Alchian, "Evolution, Economic Theory and Uncertainty," Journal of Political Economy, LVIII (I950), $2 \mathrm{II}-22 \mathrm{I}$, reprinted in idem, Economic Forces at Work (Indianapolis, I977), I 5-35. For Blackstone, see Commentaries III, 266-268, 325-330, 378-384, $42 \mathrm{I}-444$.

39 Critical discussions of the Coase theorem and the transaction-cost analysis of law include C. Edwin Baker, "The Ideology of the Economics Analysis of Law," Philosophy E Public Affairs, V (I975), 3-48; Jules Coleman, Markets, Morals and the Law (Cambridge, I 989); Cooter, "The Cost of Coase"; idem, "Coase Theorem," in The New Palgrave, I, 457-460; Donald H. Gjerdingen, "The Coase Theorem and the Psychology of Common Law Thought," Southern 
A final criticism concerns the amoral concept of causation that imbues Coase's theory-perhaps its most original and problematic aspect. Coase suggested that costs imposed by property users on one another are mutual costs, caused reciprocally, in which one property use conflicts with another. In his vision, costs are not "caused" by one active party at another passive party's expense, for each party's activity affects the other. This notion of reciprocal causation distinguishes Coase's theory from Pigou's theory of social cost, in which property entitlements are not simple costs but externalities, or nontransacted effects, caused unilaterally by the active property holder affecting other passive neighbors. According to Pigou, clear property rights were desirable because they made for readier internalization of the external costs of the active or causative party, not because clear property rights helped the identification of the cheapest cost avoider within a system of interacting owners. Coase's abandonment of moral, or responsible, causation disrupts our intuition that the integrity of persons and property from interference is often morally valuable and is not merely a tradeable preference for a particular distribution of rights. This moral lacuna is a feature of the positive economics tradition of atomistic individualism within which Coase worked. For Coase, the possibility of private gains imposing social or public costs vanished, because there was no "public" distinct from transacting, interacting individuals. ${ }^{40}$

The Coasean vision of the role of law, property rights, and transaction costs in economic development continues to excite

California Law Review, LVI (1983), 71 I-760; Kelman, "Consumption Theory, Production Theory and Ideology in the Coase Theorem," Southern California Law Review, LII (I979), 669-698; idem, A Guide to Critical Legal Studies, II4-I85; Kennedy, "Cost-Benefit Analysis of Entitlement Problems: A Critique," Stanford Law Review, XXXIII (I98I), 387-445; Kennedy and Michelman, "Are Property and Contract Efficient?"; Steven G. Medema, Ronald H. Coase (Basingstoke, I994); Mishan, "Pareto Optimality and the Law"; Pennock and Chapman (eds.), Ethics, Economics, and the Law, 3-IO2; A. Mitchell Polinsky, "Economic Analysis as a Potentially Defective Product," Harvard Law Review, LXXXVII (I974), I655I68I; "Symposium on Efficiency as a Legal Concern," Hofstra Law Review, VIII (1980), $485-770$.

40 Arthur Pigou, The Economics of Welfare (London, I932; 4th ed.), 172-203. The ramifications of reciprocal causality are investigated in Richard Epstein, "Causation and Corrective Justice," Journal of Legal Studies, VIII (I979), 477-504; idem, "Nuisance Law: Corrective Justice and Its Utilitarian Constraints," Journal of Legal Studies, VIII (I979), 49-102; idem, "A Theory of Strict Liability," Journal of Legal Studies, II (1973), I SI-204; Hart and Honoré, Causation in the Law (Oxford, I985; 2d ed.), 1xxiii-lxxvii; Horwitz, Crisis of Legal Orthodoxy, 5I-63. 
the imagination of modern economic historians and institutionalists on the margins of neoclassical theory, notably North, who analyzes the historical rise of the Western economies in terms of the development of definite property rights permitting low-cost transactions. North's investigation stresses the rise of a powerful central state, able to define and defend property and contract rights and raise steady taxation from property holders for police functions. ${ }^{41}$

The Interest Group Theory-Rent Seeking The Marxist tradition proper has shown remarkably little interest in the legal forms of capitalism. The content of legal rules and procedures is seen to be less important than the overall function of law as an instrument of class power. Some Marxist economic historians have attended to Weber's problem of the role of English law in Britain's modernizing economy, but have found little to note. ${ }^{42}$

Neoclassical and new institutionalist theorists have been left with the task of developing articulate models of private property as an aspect of power. The "interest group theory" sees much of the structure of property rights as a means of monopolist rent seeking at communal expense. In a recent study of contemporary institutional economics, Eggertsson refers to the transaction-cost analysis of property rights as "the naive theory," because it "seeks to explain the development of exclusive property rights without explicitly modelling social or political institutions." By contrast, the interest group theory (which can be aligned with public choice theory) emphasizes that the sectional and selfish interests of both regulating state agencies and regulated actors can result in property rules favoring certain interests at variance with the most efficient or just arrangements - for example, by rewarding those interests with "rents" through legal control of resources. As Libecap writes,

4I North and Robert P. Thomas, The Rise of the Western World: A New Economic History (Cambridge, I973); North, Structure and Change in Economic History; idem, Institutions, Institutional Change and Economic Performance; and idem, "Economic Performance Through Time." 42 Thompson, Whigs and Hunters: The Origin of the Black Act (London, I975), 206-267; Alan Hunt and Maureen Cain, Marx and Engels on Law (London, 1979); Hugh Collins, Marxism and Law (Oxford, I982); Christine Sympnowich, The Concept of Socialist Law (Oxford, I990); Alan Hunt, "A Socialist Interest in Law," New Left Review, CXCII (I992), I05-I I9; see, for example, Eric Hobsbawm, The Age of Revolution 1789-1848 (London, 1962; repr. I977), 68; Randé Kostal, Law and English Railway Capitalism, 1825-1875 (Oxford, I994); Rubin and Sugarman, "Law and Material Society." 
Competitive forces tend to erode institutions that no longer support economic growth. Changing market conditions exert pressure for dynamic adjustments in the existing rights structure through refinement of rights and privileges or their transfer to others . . . to facilitate responses to new economic opportunities. Predictions regarding the way in which property rights arrangements respond over time to changing economic opportunities, however, must carefully consider political and equity factors. Distributional conflicts arise when property rights are coercively redistributed by the state with little or no compensation. . . . Disadvantaged parties will oppose the new arrangement, even though it allows for an aggregate expansion in production and wealth. Accordingly, analysis of the likely winners and losers of economic and institutional change and their interaction in the political arena in specific settings is necessary before the observed pattern of property rights can be understood. ${ }^{43}$

Bringing this understanding to bear in analyzing the judicial power of government, some public choice theorists argue that judges can and do promote suboptimal property arrangements because of their class, social bias, or perceived self-interest. Moreover, the very institution of adjudicating, or choosing between the demands of noncooperating individual litigants, can lead to worse results than would be the case if property rights were designed with the whole picture of the litigants' sphere of activity in mind. ${ }^{44}$

Legislative and executive government are predisposed to control by groups seeking institutional support for their interests. Olson has argued that the agencies of governmental power (legislatures, executives, and courts) in relatively decentralized states, such as eighteenth-century Britain, do not control economic life, and so property rights are not likely to be captured by pressure groups and used as monopolies extracting rents and strangling

43 Gordon Tullock, "Rent Seeking," in The New Palgrave, IV, I47-I49; Eggertsson, Economic Behaviour and Institutions, 250; Libecap, "Property Rights in Economic History: Implications for Research," Explorations in Economic History, XXIII (I986), 227-252, 227-228. 44 See, for example, William Landes and Posner, "The Independent Judiciary in an Interest-Group Perspective,"Journal of Law and Economics, XVIII (I975), 875-901; Posner, Economic Analysis of Law, 519-537. Rational-choice theory and game theory are now coming to be applied extensively to legal-economic decision making: see references in Cooter, "Coase Theorem"; Amartya Sen, "Rational Behaviour," in Eatwell, Milgate, and Newman (eds.), The New Palgrave, IV, 68-76. 
innovation. Thus, on his view, the clear definition of property rights is less important than the institutional and political environment in which property rights are allocated and enforced. ${ }^{45}$

Contractarian Theory-Replacement of Trust Relations with Atomistic Negotiation The contractarian theory ascribes the development of property to the movement from status relations to contracts. It characterizes the emergence of new forms of property as a profound social change from closely knit and inflexible customary and trust relationships governing the use of resources (for example, stinted commons in the open-field system of European agriculture) to fluid, atomistic, individualistic negotiations and contracting of one-off relationships. Individual property rights emerged out of precapitalist common and public rights to express this new form of social interaction. The law permits expropriation without compensation of the economic interests of individuals in communal or public property, for these interests are supported by old customary relationships, not by a legal system that accords standing only to defined individual rights of exclusive or stinted access to resources. With the emergence of private-property rights, the legal system continued to search for individualistic bases for rights of property, contract, and tortious compensation, such as agreement, consent, or fault, and moved away from more traditional notions of customary and prescriptive right or mutual responsibility. Other versions of this general historical interpretation have argued that individualist ideals in the nineteenth century

45 James Buchanan and Gordon Tullock, The Calculus of Consent: Logical Foundations of Constitutional Democracy (Ann Arbor, 1965); Tullock, Private Wants, Public Means: An Economic Analysis of the Desirable Scope of Government (New York, I970); idem, The Logic of the Law (New York, I97I); idem, "Public choice," in Eatwell, Milgate, and Newman, The New Palgrave, III, I040-I044; Dennis Mueller, Public Choice II (Cambridge, I989); Mancur Olson, The Rise and Decline of Nations: Economic Growth, Stagflation, and Social Rigidities (New Haven, I982), 77-87.

An early instance of an interest-group approach to common-law doctrine is found in Bohlen's I9I I analysis of the Rylands $v$. Fletcher rule of strict liability in property and tort law, which Bohlen describes in terms of the class identification of judges with traditional landowners against the entrepreneurial classes of the Industrial Revolution. Rylands $v$. Fletcher (I865-68) I 59 English Reports 737 (Exchequer); Law Reports I Exchequer 265 (Exchequer Chamber); Law Reports 3 House of Lords 330 (House of Lords); Francis H. Bohlen, "The Rule in Rylands v Fletcher," University of Pennsylvania Law Review, LIX (I9II), 298, 373, 423, reprinted in idem, Studies in the Law of Torts (Indianapolis, I926); see also Simpson, "Legal Liability for Bursting Reservoirs"; Clare Dalton, Losing History: Tort Liability in the Nineteenth Century and the Case of Rylands v Fletcher, unpub. ms. (Harvard University Law School, I987); Samuel J. Stoljar, “Concerning Strict Liability," in Paul Finn (ed.), Essays on Tort (Sydney, I989), 267-293; cf. Burnie Port Authority v. General Jones Pty. Ltd. (I994) I79 Commonwealth Law Reports 520 (High Court of Australia). 
led contract law to adopt free consensual bargain, realizing the subjective will of the parties as the touchstone of liability, rather than notions of objective fair exchange. In the same period, strict tort liability enforcing full compensation for injury to property and persons was rejected as a redistributive communal coercion that reduced the autonomy of free individuals. ${ }^{46}$

The individualist property ideal was restated in stark terms by Chambers and Mingay to defend the enclosure of common lands in England:

The legal owners of common rights were always compensated ... with an allotment of land. (The occupiers of common right cottages ... who enjoyed common rights by virtue of their tenancy of the cottage, received no compensation because they were not, of course, the owners of the rights. This was a perfectly proper distinction between owner and tenant, and involved no fraud or disregard for cottagers on the part of the [enclosure] commissioners.)

The values assumed by Chambers and Mingay were noted by Thompson in The Making of the English Working Class: "[W]hat was "perfectly proper" in terms of capitalist property relations

46 Influential statements of this thesis have come from economic anthropology - for example, the idea that societies progress "from Status to Contract": Henry Maine, Ancient Law (London, I86I; 2d ed. I906), I8I-I82; or the idea of a shift from exchange by reciprocal gift to monetized contract: Marcel Mauss (trans. Ian Cunnison), The Gift (London, I954); Karl Polanyi, The Great Transformation: The Political and Economic Origins of Our Time (New York, I944; repr. 1957); idem, Primitive, Archaic and Modern Economies (Boston, 1971); on the rise of contractualism, see Macpherson, "Capitalism and the Changing Concept of Property," in Eugene Kamenka and Ronald S. Neale (eds.), Feudalism, Capitalism and Beyond (London, 1975); idem, The Political Theory of Possessive Individualism; Rose, "Comedy of the Commons"; Simpson, History of the Land Law, I03-I18; Atiyah, The Rise and Fall of Freedom of Contract (Oxford, I979), 85-90; Rubin and Sugarman, "Law and Material Society," 23-42; Peter Stein, Legal Evolution (Cambridge, 1980), 69-127; Thompson, "Custom, Law and Common Right," I59-I75; cf. Richard Hoyle, "Tenure and the Land Market in Early Modern England: or a Late Contribution to the Brenner Debate," Economic History Review, XLIII (I990), I-20. For powerful criticism of the individualist-ideals interpretation, see John L. Barton, "The Enforcement of Hard Bargains," Law Quarterly Review, CIII (1987), I I8-I47; David J. Ibbetson, "Consideration and the Theory of Contract in Sixteenth Century Common Law," in Barton (ed.), Towards a General Law of Contract (Berlin, I990), 67-I23; Simpson, "The Horwitz Thesis and the History of Contracts." On changing tort liability, see Atiyah, "Liability for Railway Nuisance in the English Common Law: A Historical Footnote," Journal of Law and Economics, XXIII (I980), I9I-I96; Joel Brenner, "Nuisance Law and the Industrial Revolution," Journal of Legal Studies, III (1974), 403-433; Dalton, Losing History; Kretzmer, "Transformation of Tort Liability"; John P. S. McLaren, "Nuisance Law and the Industrial Revolution: Some Lessons from Social History," Oxford Journal of Legal Studies, III (I983), I 55-22I. 
involved ... a rupture of the traditional integument of village custom and of right: and the social violence of enclosure consisted precisely in the drastic, total imposition upon the village of capitalist property-definitions." 47

Chambers acknowledged that, legalities aside, the cottagers' loss of access to the commons might not be balanced materially by the substitution of small and unviable private plots, and could result in immiseration, even if in the longer-run aggregate productivity and population were increased by enclosure. This evaluation of the enclosure of the commons in terms of aggregate utilities again diverts attention from the nature of social relationships expressed in and determined by property rights. Recent scholarship has detailed the adverse impact of enclosure on the common rights, lifestyles, and livings of the poor in farming, gathering, gleaning, and hunting. ${ }^{48}$

Internalist Legal Explanations-Rationalization of Judicial Governance Orthodox legal historians are suspicious of functionalist explanations of the evolution of law that emphasize purposes outside the bounds of specifically legal reasoning. They look, instead, to internal legal arguments and procedures to explain the emergence of particular forms of property. Close attention is given to the history of doctrines such as negligence, strict liability, license, estoppel, prescription, customary, and natural rights; the forms of action including trespass, case, and nuisance; procedural changes in the presentation of evidence and the roles of judge and jury; the balance between centralized rules and local custom; and, more abstractly, the shifting concepts of will, agreement, foresight, and causation. Such legalistic concerns are placed at the center of explanation of the development of legal compensation policies.

47 Jonathan D. Chambers and Gordon E. Mingay, The Agricultural Revolution 1750-1880 (London, 1966), 97; cf. Sheila Lambert, Bills and Acts: Legislative Procedure in Eighteenth-Century England (Cambridge, 1971); Thompson, Making of the English Working Class, 238.

48 Chambers, "Enclosure and the Labour Supply in the Industrial Revolution," Economic History Review, V (1952-53), 319-343, 336; Frank Sharman, "An Introduction to the Enclosure Acts," Journal of Legal History, X (1989), 45-70; Robert Allen, Enclosure and the Yeoman: The Agricultural Development of the South Midlands 1450-1850 (Oxford, I992), 235-3 II; Janet M. Neeson, Commoners: Common Rights, Enclosure and Social Change in Common-Field England, 1700-1820 (Cambridge, I993); Thompson, "Custom, Law and Common Right"; idem, Whigs and Hunters; Peter King, "Gleaners, Farmers and the Failure of Legal Sanctions in England 1750-1850," Past and Present, I25 (1989), II6-150; idem, "The Origins of the Gleaning Judgement of 1788, A Case Study of Legal Change, Customary Right and Social Conflict in Late Eighteenth Century England," Law and History Review, X (1992), I-3 I; P. B. Munsche, Gentlemen and Poachers: The English Game Laws 1671-1831 (Cambridge, I98I). 
Traditional legal history demonstrates that shifts in property forms do not track broader social and economic changes by neat cause and effect, and that explanation of broad historical changes is incomplete without close understanding of the internal evolution of law and the professional culture of lawyers, as well as the external context of the law. "The rational study of law is still to a large extent the study of history," wrote Holmes in I897, and Ioo years of radical law reform, legislation, and social transformation have not outdated his dictum. ${ }^{49}$

SUMMATION AND ENVOI According to classical social and economic theory, markets are constituted by the development and trade of clearly defined property rights. Conversely, markets constitute property rights themselves through transactions between private individuals who wish to define and stabilize their entitlements and thereby maximize investment, production, and exchange. The legal and institutional history of the development of property rights in industrializing England shows that there was a large public and political dimension to private property rights that transcended market behavior and that there was an inherent instability in property as a monopolist power to enjoy resources continually threatened by competitive injury from rival developers. Weberian and economic theories describe property simply as a basis of certainty and prediction. Parsimonious explanations such as these are valuable as a basis for useful generalization; but new property theory and new historical arguments suggest that legal institutions of property have a more complex role in shaping the course of economic development. It is ironic that property-rights theory, which was first cultivated to correct the exaggerated abstraction of classical social and economic theory, should now itself stand in need of fresh infusions of legal, institutional, and historical thought.

49 Gordon "Historicism in Legal Scholarship," Yale Law Journal, XC (1981), 1017-1056; idem, "Critical Legal Histories," Stanford Law Review, XXXVI (1984), 57-125; Holmes, The Common Law; Pollock and Maitland, The History of English Law; William S. Holdsworth, A History of English Law (London, I903-1972), I 3v.; Milsom, Historical Foundations of the Common Law; idem, Studies in the History of the Common Law; Baker, Introduction to English Legal History; Simpson, A History of the Common Law of Contract: The Rise of Assumpsit (Oxford, I975); idem, History of the Land Law; idem, Leading Cases in the Common Law (Oxford, 1995); Stoljar, A History of Contract at Common Law (Canberra, 1975); Oliver Wendell Holmes, "The Path of the Law," Harvard Law Review, X (I897), 457-478, 469. 